\title{
Brennhet behandling
}

Om anvendelsen av lokale 1ste grads forbrenninger som terapevtikum spesielt ved innvendige lidelser.

\author{
Av Alf Tellefsen, Furuly Helseheim, Stord.
}

Anvendelsen av kviksølvkvartslys har som bekjent forlengst brutt den nøiaktige indikasjonsstillings skranker. Dette delvis p. gr. a. kosmetiske og reklamemessige interesser, men delvis også p. gr. a. lægenes mangelfulle kjennskap til fysioterapi. Dette siste forklarer vel også at tross «høifjellssolens» almindelige utbredelse er behandlingen med lokal, 1. grads forbrending, så vidt jeg vet, omtrent ikke anvendt her i landet - uten mot lidelser i huden selv.

Etter at jeg nu har prøvet behandlingen her på Furuly Helseheim i ca. 4 år med opmuntrende resultater, skal jeg referere dens fysiologiske grunnlag, teknikk og indikasjonsområde.

Man ønsker å opnå en virkning i et dypereliggende organ ved å fremkalle et kraftig erytem i et dertil svarende hudfelt. Behandlingen er forsåvidt bare en fornyelse av den gamle derivasjonsterapi. Det kjente forhold at der ved visse sykdommer i bestemte indre organer kunne påvises hypersensible hudsoner med konstant beliggenhet, forklarer Carl Lange i 1875 således: Irritamentstrømmen fra de syke organer går gjennem afferente sympatiske baner til med. spinalis, p. gr. a. sin styrke «springer de over» på de sensible nervebaner som kommer inn i samme nivå, hvorefter bevisstheten projiserer disse impulser til nervenes utbredningsområde (altså en viscero-sensibel refleks). Impulser som utenfra treffer dette område (en såkalt Heads sone), vil så opfattes sterkere enn normalt.
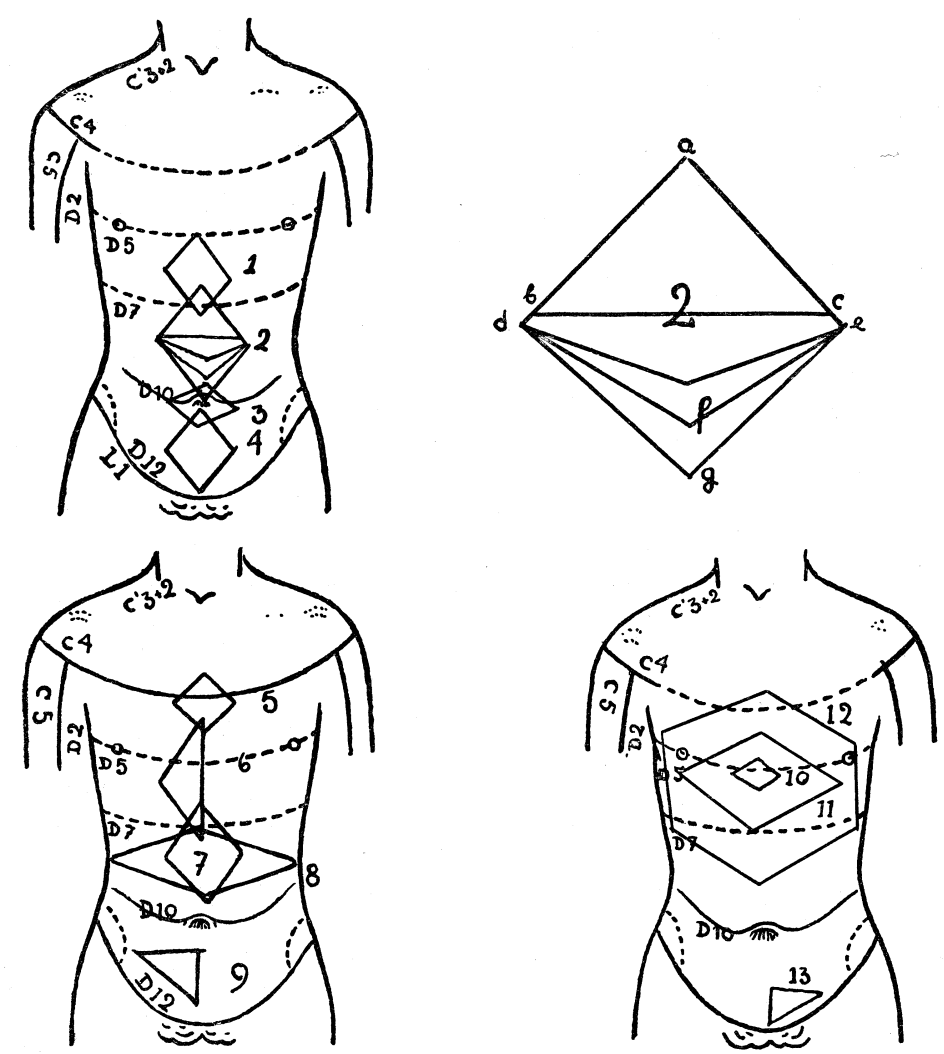

Fig. 1.

1: Cardia-striktur. 2 abc: Pylorusstenose. 2 ade: Cholelithiasis. 2 adge: Uleus duodeni. 3: Enterit. 4: Colit. 5: Tracheit. 6: Bronchitis dext.. 7: Asthma. 8: Uterine lidelser. 9: Pneumoni (dext.). 10: Perikarditt. 11: Angina pectoris. 12: Aortitis. 13: Ureter-kolik. 14: Gastrit. 15. Enterit. 16: Colit. 17: Cancer recti. 18: Aneurysma arcus aortae. 19: Bronchitis sin. 20: Nefrolithiasis. 